University of Warwick institutional repository

This paper is made available online in accordance with

publisher policies. Please scroll down to view the document

itself. Please refer to the repository record for this item and our

policy information available from the repository home page for

further information.

To see the final version of this paper please visit the publisher's website.

Access to the published version may require a subscription.

Author(s): Peter Burnell

Article Title: Legislative Strengthening Meets Party Support in

International Assistance: A Closer Relationship?

Year of publication: 2009

Link to published version :

http://dx.doi.org/ 10.1080/13572330903302505

Publisher statement: none 


\section{Legislative Strengthening meets Party Support in International Assistance: a}

\section{Closer Relationship?}

\section{PETER BURNELL*}

Recent reports recommend that international efforts to help strengthen legislatures in emerging democracies should work more closely with support for building stronger political parties and competitive party systems. The article locates the recommendations within international assistance more generally and reviews the arguments. It explores problems that must be addressed if the recommendations are to be implemented effectively. The article argues that an alternative, issue-based approach to strengthening legislatures and closer links with civil society could gain more traction. However that is directed more centrally at promoting good governance for the purpose of furthering development than at democratisation goals sought by party aid and legislative strengtheners in the democracy assistance industry.

International democracy assistance to emerging democracies has grown steadily from the late 1980s to over US\$5 billion annually. Electoral assistance and support for civil society are well-documented features. Help with legislative strengthening and building stronger political parties and competitive party systems is more modest and has received less attention. However many countries have been the object of one or both types of support. ${ }^{1}$ And recent years have seen growing interest among international actors interested in strengthening legislatures in pioneering new

\footnotetext{
* Peter Burnell is Professor in the Department of Politics, University of Warwick, England. He would like to thank the journal's referees for very helpful comments of an earlier version of this article.
} 
approaches, ${ }^{2}$ one of which recommends closer involvement with efforts to strengthen political parties and party systems.

This article does not offer a comprehensive survey of legislative strengthening: timely reviews of varying scope are readily accessible elsewhere (for example Hudson and Wren 2007; Wehner et al. 2009). Rather it focuses more particularly on the recommendation in reports and inquiries into support for legislative strengthening for closer cooperation with assistance to party strengthening. The case for investigating this recommendation is underlined by Power's (2008: 23) observation that parliamentary and party support have in fact been 'entirely separate disciplines in terms of analysis, evaluation, and practice'. If the reasons for this state of affairs can be identified then the chances that the recommendations will be implemented successfully can be assessed more accurately. To do this, however, the issue must be introduced, first, within a broader account of organisations involved in international democracy support and the sort of activities that legislative and party strengthening involve. A second section sets out arguments in favour of the recommendation; the third section raises counter-arguments. These suggest that expectations should be moderate. The fourth section argues that different ways of approaching legislative strengthening may gain more traction. But these are geared more to promoting good governance for the purpose of promoting development than democratisation goals sought by party aid and legislative strengtheners in the democracy assistance industry. A conclusion summarises the main points.

INTERNATIONAL DEMOCRACY ASSISTANCE, LEGISLATIVE STRENGTHENING AND PARTY SUPPORT 
International democracy assistance conventionally refers to consensual and grant aided support for activities designed to help countries move in the direction of establishing and consolidating western style liberal democracy. The borderline between this and support for improving governance is blurry; good governance and democratisation are two policy agendas that often seem inextricably linked, as in the term democratic governance. But while not mutually exclusive their respective emphases are different. For instance tackling corruption (the use of public office for private gain) and its roots feature prominently in efforts to improve accountable governance, but while relevant to judging democratic performance it is less central in theories of democracy and democratisation, where ideas of participation, contestation and opportunities for the people to make political choices are fundamental. ${ }^{3}$

The many international organisations now involved in support for democratisation can be classified in several ways, even after differentiating all of them from those organisations whose main reason for supporting stronger legislatures is to ensure better governance for the end of advancing development. A leading of example of this second group is the World Bank Institute, the capacity development arm of the World Bank, whose extensive knowledge-sharing activities include producing an Orientation Handbook for Members of Parliament (2006), as well as detailed reports on parliamentary oversight for government accountability generally and budgetary matters particularly. ${ }^{4}$

\section{A patchwork quilt of democracy assistance organisations}


Some organisations assisting democratisation are multilateral, for example the United Nations Development Programme (UNDP) with an annual budget for this purpose of around \$1.5 billion; others are bilateral or nationally based, for instance Britain’s Westminster Foundation for Democracy (WFD), an independent public body with annual funding around $£ 4.1$ million from the Foreign and Commonwealth Office. ${ }^{5}$ Some are governmental, notable examples being the United States Agency for Development (USAID), whose 2009 funding bid for 'governing justly and democratically’ exceeds US\$1.7 billion, and the Swedish International Development Cooperation Agency (SIDA). ${ }^{6}$ Others have autonomous status even when funded from official sources, like the Netherland Institute for Multiparty Development (NIMD), funded by Dutch taxpayers in excess of 10 million Euros annually. Some are aid donors but like USAID and Britain’s Department for International Development (DFID) employ many others to execute projects and programmes; others are primarily operational and rely on receiving grants or contracts. These include autonomous notfor-profit entities, private consultants, commercial actors and some regional parliamentary networks.

The largest organisations like USAID are involved in a wide range of activities associated with all main sectors and sub-sectors of what Carothers (1999: 88) calls the 'democracy template' - support for the electoral process, state institutions, and civil society; others are more highly specialised: the very titles of the NIMD and the Parliamentary Centre of Canada (PCC), both of which are non-profit organisations, indicate their respective specialisms. ${ }^{7}$ The United Nations' broader commitment to nation-building and conflict resolution gives the UNDP a distinctive interest in advancing the contribution that both parliaments and parties can make to securing 
domestic peace. Whereas the main intergovernmental and some of the larger national organisations support or execute democracy support programmes and projects widely in many countries others concentrate more narrowly. An example is Australia’s Centre for Democratic Institutions (CDI), whose mandate concentrates on just parliamentary and party work, focusing on Indonesia and Pacific island states. ${ }^{8}$ All the organisations have web-sites where mission statements and descriptions can be found.

\section{Organisations and their legislative and party support activities}

Generally speaking development organisations feature much more strongly in legislative support than in political party support, but legislative strengthening is certainly not exclusive to development agencies; however, some of the organisations most committed to party support do not regard legislative strengthening as a major objective.

In regard to legislative strengthening, an initial canvas for the report Benchmarks for Democratic Legislatures (Commonwealth Parliamentary Association 2006: Foreword 4) identified approximately 19 parliamentary associations and development agencies working in the field of parliamentary democracy, as sponsor, implementer or adviser on programmes. Notable examples are the Inter-Parliamentary Union (IPU), active since the $1970 \mathrm{~s}^{9}$ and the CPA itself. The World Bank Institute (WBI) too has a strong interest, as do the NDI, a non-profit grantee of the National Endowment for Democracy (NED) funded by the US Congress, and SIDA, as well as UNDP, USAID, PCC and CDI. Britain’s DFID is currently showing considerable interest too: a recent report from the Overseas Development Institute (ODI) encourages it to do so. ${ }^{10}$ 
In regard to strengthening political parties in new or emerging democracies the international organisations include some (but not all) of the organisations already mentioned, such as UNDP, USAID, NDI (and its counterpart the International Republican Institute) and CDI but not the WBI. Others who are prominent in the world of party support but have no comparable commitment to legislative strengthening include Germany’s political foundations (Stiftungen, affiliated to Germany's political parties), political parties in several long-established democracies like Britain who befriend new parties in emerging democracies often on a partisan basis, the Norwegian Centre for Democracy Support, and NIMD which is currently involved with over 150 parties in 17 countries chiefly in Africa and Latin America. ${ }^{11}$

Just as legislatures and political parties both in theory perform several distinct functions for democracy, so legislative strengthening and party support are not single monolithic or, even, static activities. Manuals and the like have proliferated: examples are USAID Handbook on Legislative Strengthening (2000) and UNDP’s A Handbook on Working with Political Parties (2006). The main activities are described elsewhere. ${ }^{12}$ In essence, party support has traditionally concentrated on direct assistance to parties, even where one of the goals (now becoming more prominent) is to encourage the development of properties at the level of the overall party system, such as competitiveness, stability and preventing excessive fragmentation. Depending on the actor, assistance is extended on partisan (now becoming less dominant), multiparty and cross-partisan bases. USAID for example is not supposed to discriminate between democratic parties, whereas Germany’s Stiftungen have a history of partisan support. In contrast to the 1990s when much assistance focussed 
on helping new parties with election strategies and campaigning skills, party institutionalisation in the longer-term is now a major object. This includes party organisation, fund-raising, message development and policy research skills. What Carothers (2006: 114-5) calls the 'standard method’ comprises advice, training, some material aid, workshops and seminars, and exchange visits. More prosaic, CDI says its annual political party development course 'covers the nuts and bolts of party politics from the inside ${ }^{13}$ NIMD's interest in post-conflict societies gives it a special interest in brokering cross-party consensus on rules of competitive behaviour.

Legislative strengthening similarly comprises an assortment of activities, with different organisations having different emphases; the overall balance too has tended to evolve over time. ${ }^{14}$ For USAID a Legislative Strengthening Advisor has listed the goals or objectives as more effective, independent, and representative legislatures; more effective and democratic internal management systems; increased capacity to influence national policy and budget priorities; and increased citizen access. Improving legislative standards, advancing legislative development, and refining the administration and financing of parliaments are typical remits (Schultz 2007). More simply Power distinguishes structural support, which includes help with building the institutional and technical capacity of parliament (stocking libraries for instance), procedural support especially in relation to the role of parliamentary committees, and functional support for improving MPs' ability to understand and perform their representative, legislative and oversight functions. He notes that the concentration on structural support which characterised earlier decades has since broadened out to the other forms (Power 2008: 4-5). ${ }^{15}$ UNDP specifically has diversified away from support to parliaments' law-making and representation functions towards 
parliamentary oversight (especially in Africa), an aspect where development aid donors exhibit a strong interest in regard to financial oversight especially. Training sessions, workshops and study visits still provide popular mediums.

There is increasing discussion in some of the recent reports on legislative strengthening about the need to move further in the direction of grappling with the parliaments' political environment, meaning the political incentive structure that faces MPs. ${ }^{16}$ This can be understood as a reference to the compelling demand - framed by the neo-patrimonial and clientelistic political cultures typical of many developing countries - on MPs to deliver government spending on essential public goods and services to their constituents. This emphasis is often thought to deflect parliamentarians from spending time and energy on other essential parliamentary functions. ${ }^{17}$ Political parties are also important in shaping the incentive structure.

\section{Closing the gap}

As shown, although the organisations involved in legislative strengthening and in party support are not identical the clusters do overlap. And yet the two areas of activity have tended to proceed in parallel and along separate lines, even when funded or, even, carried out by the same organisation. ${ }^{18}$ Recommendations in a number of reports on legislative strengthening are that the gap should be closed in the interests of improving the performance of legislative strengthening, where the evidence from evaluations indicates much scope exists for raising effectiveness. The recommendations are not echoed to anything like the same degree by supporters of party assistance, ${ }^{19}$ and nor do they claim to have the solution for more effective legislative support. Furthermore not every organisation now showing a strong interest 
in legislatures is keen to engage with parties. The WBI is a case in point. This is in keeping with the constraints on political involvement that are placed on the World Bank by its mandate as a development bank which at all times must value good working relations with governments. Indeed Hubli and Schmidt (2007: 23) even claimed that 'many Bank officials still equate active support for parliamentary involvement with political interference', although even if once true their claim has been overtaken by evolution in the Bank’s governance and anti-corruption strategy, which now calls for the Bank to support parliaments.

Nevertheless, an accumulating body of opinion does appear to consider the idea of some form of coming together of legislative and party work attractive. Almost a decade ago USAID’s Handbook on Legislative Strengthening (2000: 23) mentioned the desirability of taking more account of party structures and dealing with party system fragmentation; then UNDP (2003: 13) signalled renewing its attention to parties as 'critical actors', because 'building more democratic and functional parties is an important aspect of parliamentary development'. ${ }^{20}$ Recently the chorus has swelled: in 2007 an evaluation of SIDA's legislative support recommended improved ‘coordination and integration’ of parliamentary and political party programming (Hubli and Schmidt 2007: 7). And in Britain in 2008 first an ODI report to DFID (Hudson and Wren 2007: 48) and then a report by AAPPG observed that parliamentary development is linked to the state of the parties. Hudson and Tsekpo (2009: 5), from ODI and PCC respectively, elaborate that in order to support the emergence of parliamentary democracy as competition between ideas and agendas, international partners 'urgently need to engage more effectively' with parties. The AAPPG invites DFID to consider working with leading political party institutes, to 
support the development of parties: 'There is insufficient coordination between the work of organisations providing support to political parties and the work of development partners providing support to parliament. This must change' (AAPPG 2008: 11). Of the organisations for whom party building has been their main commitment, one that stands out here is the Westminster Foundation for Democracy (WFD), whose Chief Executive, David French (2008), wants WFD to become more involved in parliamentary strengthening. ${ }^{21}$

However, notwithstanding all the above, the fact that nearly ten years ago USAID (2000: 63) called the role of parties in legislatures not just an 'emerging issue' for legislative strengthening but one 'where progress can be expected to proceed only slowly', and that nine years on fresh calls for this to happen are on the increase, tel us the path will not be easy. Before the obstacles are identified, however, the next section first draws out arguments in favour of the recommendation.

\section{SUPPORTING ARGUMENTS}

The case for a closer relationship depends to some extent on the precise nature of the recommendation. Usually this is left unclear. Different terms like greater coordination, cooperation, and integration are used but not defined in any detail: the full implications for projects or programmes and no less important for organisational arrangements both between and inside the relevant institutional actors are not spelled out. There is a considerable difference between sharing experiences, which to some extent already happens, and the systematic integration of assistance intervention strategies in advance. Nevertheless, three supporting arguments that appear to underlie the recommendations can be teased out below. 
First, while at one level legislative strengthening and party support are both committed to advancing the cause of democratic governance current evidence points to some shared limitations. This prompts an inference that joining forces in some way will make it easier for the weaknesses to be overcome (see Power 2008).

Perhaps the most salient shared characteristic here is that parliamentary and party assistance are generally judged to be the most politically sensitive areas of international democracy assistance. This may explain why they have been less favoured than other forms such as capacity building in civil society, although that too can attract political complications. However the sensitivities are not all identical. External involvement with a country's legislature - the supreme law-making body touches directly on issues of national sovereignty; involvement with parties carries risks of being construed by the government in partisan terms, even when support is offered on a multiparty basis. Partisanship is inescapable where international donors shun parties whose democratic credentials are weak or have unacceptably racist, tribal, sexist or xenophobic agendas.

That said, in some countries in Africa for instance even parliamentary strengthening is said to run 'the risk of being identified with short-term partisan political agendas' (AAPPG 2008: 45). Governments may interpret even these efforts as a direct challenge, in one party dominant states for instance. However, clearly this is different from suspicions arising from local concern about the underlying policy intentions of external actors, which in the case of foreign aid donors, the Bretton Woods Institutions particularly, may be bound up with their advice on the kind of neo-liberal 
macro-economic measures and public expenditure control that donors believe vital to development. Here parliamentarians across all parties may have common anxieties about external imposition, if not objecting also to the actual policy substance; opposition party politicians, denied the increased patronage that aid brings to the government side, have grounds for being even more antipathetic than government supporters. The growing interest that some aid donors now evince in strengthening legislatures for the purpose of advancing the national commitment to pro-poor development broadens the policy agenda, but far from bringing the age of foreign aid conditionality to an end it can be viewed as adding yet a further new twist.

Second and moving beyond simple observations that legislative and party support invite strong politicisation, there is an underlying albeit barely articulated rationale for combining efforts stemming from the idea that the state of parliaments and the condition of the parties are mutually interdependent, almost everywhere. A weak legislature that has limited formal powers is bad for the political parties, whether the system is presidential, parliamentary or hybrid. In legislatures overawed by executive domination opposition parties may wither between elections, especially where floorcrossing is allowed. The chances of establishing a competitive party system are reduced accordingly. The scenario can then become self-perpetuating: weak parties or a dominant party system undermine the capability of the legislature and its chance of enjoying real autonomy. Putting increased resources at the disposal of parliament and training exercises may do little to change the situation. Lack of public trust in the parties and their viability will reflect badly on confidence in the legislature. Conversely, a legislature that looks badly organised or remote from the people damages public perceptions of political parties and politicians - actors who tend to be 
among the least trusted of all public institutions, according to successive opinion surveys in many new democracies.

The upshot then is that improvements to the legislature and to the parties can go hand in hand: there is a synergy. After all, the same type of actor - and the same individuals even (MPs) - define the membership of legislatures and sit at the top of the pyramid of political party organisation. This distinguishes the potential nexus between much legislative and party work from other combinations of support to democratic governance that involve very different partners and stakeholders, ranging from professional bureaucrats to civil society leaders. And yet not all the benefits to parties and legislatures from a more joined-up approach to support can be expected to occur simultaneously; some sequencing is inevitable, especially where reform programmes must be implemented gradually and the indirect effects take time to materialise. These considerations should inform how recommendations for a closer relationship are put into operation, to avoid disappointment later. And more thought could be given to why one of the world's most powerful legislatures, the US Congress, can coexist with parties that look very weak by West European standards, in contrast to Britain, where historically parties have been strong but parliament has been criticised for being weak vis-à-vis the executive (Weir and Beetham 1999).

Third, there is the recommendation found in some reports on legislative strengthening that more effort should be given to raising the demand for parliamentary reform from the countries themselves, contrary to a supply-drive approach (see for example Hudson and Wren 2007: 48). This two-pronged argument for establishing greater local 'ownership' says the impetus must originate from within the country, not 
international 'donors', and that to be effective especially in countering resistance by governments and their supporters in parliament the reform agenda must come from society, pushed from the 'bottom up'. Looking to parliament for a parliamentary development plan may prove fruitless, as Hudson and Tsekpo 2009 found in Cambodia and Tanzania. The political case for working across the parties both inside and outside parliament gains accordingly. It is parties in parliament who must agree to legislate reforms affecting parliament that will help it to become a stronger instrument of representation, pass good laws and hold the executive to account. Conversely the state of the parties and party system are a function in part of legal arrangements covering eligibility for registration as a party, party funding, codes of electoral conduct and media access: so, legislative initiatives matter to the political parties. ${ }^{22}$

\section{GROUNDS FOR CAUTION}

The recommendations urging a closer relationship of legislative strengthening and party support naturally do not outline arguments against. But grounds for being cautious about the merits and sceptical that successful measures to implement the recommendations will emerge soon merit discussion. Five broad points will be made here.

\section{Limitations of the arguments}

First are the limitations of the very arguments that have been offered in support. Take the issue of political sensitivities. It is difficult to see how multilateral aid donors wanting to support legislative strengthening can benefit from courting the risk of being drawn closer to partisan conflicts between parties, let alone the factional and 
personal rivalries often found inside parties, even if good relations with the government can be maintained. The danger of being associated with parties that subsequently move in an illiberal direction or abuse public office when given the chance would be ever present. Take also the potential for manufacturing win-win situations for parties and legislatures. Not all party work guarantees a favourable outcome for the legislature; strengthening a dominant party may actually worsen the situation. Conversely training that helps MPs understand better the more technocratic side of government can contribute to widening the gap between the party in parliament and/or in office and the party in the country, accentuating further an already weak social rootedness. And finally, take the question of ownership: in countries like China and Vietnam where meaningful political pluralism is disallowed or the ruling party very hierarchical, or international support to parties is severely constrained, opportunities for employing parties to cultivate a bottom-up approach to legislative strengthening are restricted.

\section{Partnership matters}

For changes to modes of international assistance to work effectively the agreement of all the main stakeholders is essential. And yet while the reports recommending a closer relationship of legislative and party support draw on fact-finding inside the countries, and occasionally reproduce local opinion saying the state of the parties influences parliamentary effectiveness parliament, ${ }^{23}$ they offer scant evidence of local thinking about how to turn recommendations for integrated assistance into a reality. The approbation of governments who have power to block initiatives seems largely absent. This is critical. In party work there are several potential categories of partner party leaders; party officials at headquarters; grass-roots structures; sometimes 
separate branches for women and youth. Similarly in legislative strengthening there are different potential partners, who include the parliamentary staff as well as government leaders in the assembly, and MPs of all affiliations. Universal agreement on what needs to be done, and reasons why, seems lacking. Moreover in so far as the various international actors introduced earlier have each developed their own preferred partnerships already - both in respect of countries or stakeholders inside those countries and cooperating partners drawn from the international actor ranks efforts to reshape assistance strategies now require further dialogue to identify exactly who has the will and capability to translate vague recommendations into meaningful practice. Even on its own the landscape of parliamentary strengthening is said to be 'all too often characterised by duplication, gaps in provision and high transaction costs that are borne by poorly-resourced parliaments' (Hudson and Tsekpo 2009: 6).

\section{Coordination problems}

Whereas some major legislative support actors have considerable experience of working together on a formal basis (for example around three quarters of WBI sponsored-initiatives are delivered in conjunction with partners), the party support actors generally tend to work more by themselves, or when cooperating often do so informally and on an ad hoc basis. Historically the major share of all democracy assistance and governance aid is conceived and structured along sectoral or intrasectoral lines, with little experience of genuinely cross-sectoral (as distinct from multi-sectoral) programmes. This applies both to organisations engaged in all main sectors of democracy aid and those with a more specialised if still plural focus, CDI for example. Strong moves to merge activities across sectors risk disrupting the 
functional relationships that currently exist between projects or programmes within sectors, as well as having implications for relations among the various stakeholders.

Adding further complication is a parallel recommendation in debates on legislative strengthening for closer cooperation among partners across the developing democracies themselves, within a region like southern Africa. And while representatives of national parliaments can readily exchange knowledge and share insights in an organisation like the Southern African Development Community Parliamentary Forum, helped if needed by financial or other assistance from an outside body like the Association of European Parliamentarians for Africa (AWEPA), linking this in to closer engagement with support for the region's many political parties introduces extra political and bureaucratic challenges that could prove just overwhelming.

That existing differences among the international actors in terms of size, organisational structure and political sensitivity will colour responses to recommendations for a closer parliamentary/party support relationship is not the only point: the consequences of (selective) involvement must be considered too. For instance one projection is that the providers of multi-party and cross-party support would be placed at an advantage relative to party support providers who, like Germany’s Stiftungen, have often preferred a more partisan approach. And if, as has been suggested in the context of Sweden and SIDA, official funding for legislative strengthening draws in party support and begins to impose its own monitoring and supervision requirements, then the political autonomy cherished by party aid providers will be put at risk (see Öhman, Öberg, Holmström, Wockelberg and Åberg 
2004). In contrast Fukuyama and McFaul’s (2007-08: 40) conclusion that governments such as the US should not by themselves provide technical assistance to political parties anywhere, carries its own bias affecting the combinations of legislative and party support organisations who can 'do business' together - also with consequences for the relative standing of the different actors inside each of the two sectors of democracy support.

The different timescales for legislative strengthening and party support introduces a further complication. Legislatures are endowed with permanency by a country’s constitution; in new democracies many political parties inevitably have a short life. In theory advice on reforming the powers and procedures of a legislature can be put into effect quickly; building parties that can endure electoral defeats requires a much longer term commitment. While party support must also be nimble enough to recognise that parties in terms both of their electoral popularity and parliamentary representation can rise as well as fall very quickly, 'many years of sustained engagement' are usually required to build parliamentary effectiveness (Hudson and Tsekpo 2009: 7). These differences matter not least for the possibility of designing timely and appropriate evaluations of assistance interventions, bringing together legislative and party support. There is more pressure than ever before to subject democracy assistance to rigorous evaluation. For example in late 2008 UNDP and International IDEA commissioned research into the usefulness of IDEA's 'Research and Dialogue with Political Parties', and USAID began commissioning a two-year evaluation of its own party assistance. So far evaluations of democracy support have encountered significant difficulties and disagreements (see Burnell 2007). By appearing to multiply programme objectives the meshing of legislative and party 
support efforts could further compound the difficulties of reaching consensus on a credible approach to evaluation - and on the findings.

Finally, a remark often heard from democracy assistance practitioners is that their approach must always retain the facility to be flexible and seize on opportunities, which can arise unexpectedly. Projects and programmes may have to be refashioned in mid-term in response to changing political circumstances. Also, in hostile environments like Belarus useful party work has to be covert or confidential. These properties are more difficult to accommodate within a coordinated regime that requires a strong measure of forward planning, detailed allocation of tasks and bureaucratic organisation.

\section{Tensions among objectives}

More coherent than across-the-board recommendations, then, a selective approach to combining legislative and party support activities must acknowledge that possibilities exist for tensions as well as synergies. Indeed, where an illiberal civilian government's reluctance to embrace greater democracy or the democratic shortcomings of the party in power make all-party support unappealing to international actors, suggestions that party and legislative support should be combined are unlikely to gain much headway. If ownership by the government is made a requirement then the government has a veto power that could prove stifling. Support focussed just on opposition parties, if feasible, could be a more promising option, or, as in Zimbabwe where such support prompted government aggression against the opposition, assistance to the legislature independently is more attractive.. 
Irrespective of which approach to party support best serves to promote the objective of competitive party politics, that systemic objective does not always sit easily with a central feature of effective parliamentary oversight of the executive that makes willingness to set aside party differences, and adopt a common purpose, essential. Also, in societies emerging from violent conflict actors like UNDP look to parliament as a place where inclusive dialogue and leadership in national reunification must set examples to the people, rather than encourage the spirit of adversarial or highly confrontational politics. Where MPs face an awkward balancing act between pursuing one kind of politics in the assembly with a different, more robust contestation in the country, weaving a single 'holistic' package of external support for both legislature and parties combining all objectives will be difficult. However this does not mean the different objectives cannot be served separately: the NIMD’s distinctive approach to engaging in cross-party work for example appears to have enjoyed some success. ${ }^{24}$ However, where relations between parties in parliament are as bad as they are claimed in Lebanon it seems that the UNDP’s parliamentary programme there should concentrate on working with parliamentary officers, while efforts to assist the parties must take place somewhere else, outside the country even (Murphy and Alhada 2007: 40).

\section{Hard-to-reach independent variables}

Important factors that have influenced the effectiveness of legislative or party support and seem impervious to influence by either activity operating in isolation would continue to be hard to affect even by the two activities working in close combination. One such is the overall resource constraint. There are few grounds for thinking that additional funding will be made available and earmarked for combined initiatives. 
The ability of legislatures and political parties or of international democracy assistance generally to further democratisation is constrained by a range of variables both at home and abroad, which direct support to these institutions either separately or together cannot remove. These variables include the electoral system design (where democracy support is sometimes presented as an aspect of party or parliamentary work but is not sufficient to guarantee strong parties and healthy competition), underlying social cleavages and the political culture. The removal of power over important policy decisions to institutions of governance outside the country, foreign aid donors in particular, is a further factor. Remedies for the negative effects lie outside most democracy assistance, which by accentuating the profile of outsiders can actually make the problem worse. At the same time international development aid and governance assistance strengthen the hand of the executive. Even so, we should not forget there are limitations on legislative effectiveness and multi-party development that domestic initiatives can tackle even without international support, an example being constitutional changes that prohibit the practice of floor-crossing, as exemplified in South Africa’s National Council of Provinces in late 2008.

\section{A MORE PROMISING APPROACH TO LEGISLATIVE STRENGTHENING?}

The prospects of recommendations for aligning legislative strengthening and party support more closely should not be assessed in isolation from other recommendations currently voiced in the literature. One of the most notable is the promotion of public policy issues around which parliamentarians can be mobilised on a non-partisan basis, within the context of lending support to parliamentary processes. As an approach this 
has the potential to gain more momentum, now that multilateral and bilateral development aid donors show increasing interest in legislatures - in part as one element of a strategy to bring about improvements in public financial management, tackling corruption in particular.

Even some years ago UNDP (2003) remarked that an issue-based approach may be 'emerging as a significant means by which to expose democratic values while building the capacity of the parliament'; more recently others have identified specific issue areas where the idea could be put into practice, with macro-economic and budgetary policy, fiscal performance, and pro-poor development featuring strongly. ${ }^{25}$ In a concrete example from 2004 the UNDP in conjunction with NDI issued a threepart 'toolkit' for strengthening parliamentary involvement in the poverty reduction strategy process, with reference to achieving the UN Millennium Development Goals in particular. The same year DFID’s Policy Division produced Helping Parliaments and Legislative Assemblies to Work for the Poor (2004). Illustrative of the line of thinking more generally is Miller's (2005: 9) comment drawing on his experience at the PCC, 'it may be far more valuable from a democracy promotion point of view to have a workshop that brings parliamentarians together with other governance players from civil society, business, government to discuss health care than a half day workshop on how to conduct a parliamentary committee meeting'. Several issue areas of particular importance to building democracy through legislative involvement in policy and oversight have been largely absent from this discourse however, the security sector for instance. 
A major rationale offered for the issue approach is that it could circumvent some of the political sensitivities bedevilling party aid and direct approaches to strengthening legislatures as well, particularly on the government side. It is less threatening. Plausibly political parties too have much to gain from improving MPs’ grasp of policy but only if their increase in understanding can be institutionalised in the party structures somehow. A bonus for legislatures would be where greater attention to policy issues leads parliamentarians to give more weight to holding government accountable for policy implementation, subverting the ties of neo-patrimonial and clientelistic politics that bind them to the executive. There may also be an unspoken expectation that extra resources will be brought to legislative strengthening from the consierable funds that key development policy initiatives receive from international aid and the 'good governance' programmes attached to this end.

However, the balance of advantages that an issue-based approach could mean for political parties and even for legislatures, and for democratisation, is definitely mixed. The resistance at a conceptual and bureaucratic level to the idea of reprogramming legislative strengthening activities to support economic development activities, that has been reported at USAID (2006) for example, hints at some possible objections. Three can be cited here.

First, the idea is not suitable for every country. Just as some countries need development assistance but are not viewed as priorities for democracy assistance (because they already are democracies, or because the priorities of state-building or reconstruction must come first), or international democracy support is not welcome, so there are countries where weak legislature (and parties) could benefit from 
international engagement but have no need of development aid - oil-exporting rentier states in the Gulf, for instance. ${ }^{26}$

Second, when combining sectoral assistance defined in terms of a particular aspect of the political process or political institutions - as in legislative and party strengthening - with issue-based support related to development programmes there is the possibility that the latter will come to dominate the agenda (Hubli and Schmidt 2007: 25).

Governments with weak democratic inclinations whose legitimacy and popularity rest heavily on policy performance can be expected to encourage just such a scenario. Finding ways to evaluate international interventions that aim at a mixture of substantive policy outputs and changes in political process or institutions poses a formidable challenge: the former, being easier to design, more readily quantifiable and, very possibly, more susceptible to demonstrating tangible results quickly may influence the decision-making disproportionately: these qualities count with decisionmakers responsible for allocating resources among competing claims.

Third, an issue based approach to legislative strengthening tempts the international providers both of democracy aid and, more especially, governance assistance for development, to expand support to civil society organisations (CSOs) and nongovernmental organisations (NGOs). This already forms a distinctive growing feature of donor involvement. Not only is civil society capacity-building a well established sectoral approach to supporting democratisation but steps to involve civil society in approaches to improving governance are becoming popular with aid donors too: it can be seen as the other side of the coin of low confidence in the politicians. ${ }^{27}$ Organisations for development ranging from the World Bank to DFID increasingly 
look to CSOs not just to lobby parliamentarians but to take up policy demands and grievances directly with government ('societal accountability') and, even, engage directly with such institutions of horizontal accountability as the courts, ombudsman, national audit office and anti-corruption commission ('diagonal accountability’). ${ }^{28}$ DFID’s small Governance and Transparency fund, established in 2007, is a modest example. Much encouragement is being aimed at making governments more accountable for the way they spend public money - and hence the way that foreign is used - and to ensure development strategies of the kind that international donors prefer have more solid backing from society. But are the consequences for legislative strengthening aimed at building democracy necessarily beneficial?

\section{Civil society, development and democratisation}

Until recently parliaments as well as parties were marginalised in the efforts made by aid donors to leverage improvements in financial management by governments and shape their policies towards development. Since the introduction of poverty reduction strategies from the late 1990s civil society leaders in aid-dependent countries routinely discuss with the Ministry of Finance and international donors this aspect of public policy. However, as often as not parliaments continued to be presented with a fait accompli. A review for the World Bank and International Monetary Fund (2005) found that poverty strategies were formally presented to parliament in only a third of the countries. ${ }^{29}$

More recently this situation has begun to change, propelled by trends in development aid to advance general budgetary support in place of tied project aid and by doubts about the effectiveness of traditional aid conditionality. Both point to a case for 
strengthening the domestic instruments of accountability. Much of the increased attention now being focused on legislatures should be seen against this background. ${ }^{30}$ It has meant among other things considerable interest in helping public accounts committees and their relationship with a national audit office. An important example is the Parliamentary Strengthening Programme of the WBI, whose main objectives are to strengthen the capacity of parliaments to oversee the allocation and use of public funds, assist parliaments in better representing the interests of the poor in the policy process, and support parliamentary learning networks. Having helped to train around 10,000 parliamentarians over the last 15 years, the WBI now seeks to enhance the capacity of parliament as an institution of governance. Moreover not just the WBI and bilateral donors like DFID but even democracy support actors are now being encouraged to become more involved in helping parliaments strengthen their capacity to exercise fiscal oversight especially. Recent examples include CDI and WFD’s work with parliament's finance committee in Lebanon and Yemen's parliament. The PCC chose parliament's role in the budget process as the first model for developing specific performance indicators to implement its idea of a Parliamentary Report Card. These and other examples point to cooperation with the agenda of improving governance for development - a core concern of the donors.

Of course not only has control of the power of the purse been central to struggles over democratisation down the ages but government accountability more broadly is a fundamental attribute of democracy. Furthermore poverty reduction is consistent with a widely-held theoretical perspective that maintains there are social requisites of stable democracy. Nevertheless, for the majority of international organisations currently showing increased interest in legislative strengthening the financial, 
economic and social goals are primary, not democracy per se. And it is as an instrument for leading governments to adopt and implement efficiently and effectively policy preferences that donors believe are necessary - and which civil society leaders may be brought to endorse - that parliament seems to be valued most. ${ }^{31}$ Clearly this is not the same as giving priority to democratisation - where democratic notions that vest sovereignty in the people, value participation for various reasons and insist on inclusive representation figure in the reasoning just as strongly as accountability.

What is more, mainstream political analysis agrees that in representative democracy strong political parties remain essential for these purposes, not least by offering vehicles for society to make choices over policy, even if parties the world over display shortcomings in practice. Parties can also play a crucial role in overcoming deep social divisions after violent conflict. The claim of legislatures to provide inclusive representation, their constitutionally mandated powers to control the executive especially in parliamentary systems, and the presence of the electoral sanction that holds MPs themselves to account, all have no equivalent in the realm of civil society. There, leaders are often self-appointed, the collective coverage of society by CSOs is partial and uneven, and the actors most frequently consulted by the policy-makers may lack the popular support or membership base of the most successful parties. While CSOs too may be afflicted by weaknesses found in the parties, pervasive clientelism for instance, lacking the legal and political status of parliaments they may be more vulnerable to excessive regulation than the parties.

That some modest attention is now focussing on grounds for strengthening the connections between civil society and parliaments and other state institutions may 
prove good for development. But if the corollary means that political parties are left far behind then the overall benefit to democratisation begins to look less secure. Expressions of concern about where such developments might lead have circulated informally in discussions about party strengthening in democracy assistance for some time; a recent, perhaps even more worrying twist is suggested by the reported grievance of MPs in Malawi that external support to CSOs is 'setting civil society and parliament against one another' (AAPPG 2008: 35). ${ }^{32}$ Possibly more alarming still is yet another observer's claim that the success of civil society's growing involvement in government activities such as budget decision-making, through initiatives like participative budgeting, may actually 'depend on a weak legislature or undermine the power of the legislature' - because governments require 'space to innovate' without waiting on the legislature's consent (Krafchik 2005: 9). The final outcome, then, may include neither a vibrant party system nor a particularly strong legislature; and stronger, mutually supportive relations between the two could be even more remote.

\section{CONCLUDING OBSERVATIONS}

International interest in legislative strengthening is on the increase. There is a consensus that efforts could achieve better results. The learning curve up to now has included the idea that more effort should be put into working with parliamentarians and the political context and functioning of legislatures, emphasising less the infrastructural support and technical capabilities. Against this background the article has argued that recent recommendations for closer cooperation between legislative and party support, aimed at making the former more effective will probably make limited progress. A more detailed specification of what a closer relation means in 
practice and the implications for relationships among the different international actors, as well as for relations with local partners, must be worked out first. Here, the views of local stakeholders will be important. Yet as some have argued, in regions like Africa an exercise even more fundamental must take place first, namely thorough empirical investigation into the legislatures and their relations with parties and government (AAPPG 2008: 55). ${ }^{33}$

The reasons why largely parallel but separate endeavours have prevailed in the past will continue to pose obstacles. Some could even be compounded by closer integration. For at least some legislative strengtheners, especially in the development community, wariness of the extra political risks that come with party involvement will be hard to dispel: a preference for alternative approaches, old or new, seems likely to persist. And for at least some party support organisations, democracy institutes and party aid foundations especially, the chances that their autonomy will be threatened by forming closer ties with development aid sponsors of legislative support might weigh against joining increased cooperation.

In trying to get the balance right in democracy assistance attention should be paid not just to the distribution of total effort between the different sectors - state institutions such as parliaments, political parties, and civil society - but to the relationships among the sectors as well. More particularly, if international support for strengthening the links between civil society and the executive, parliament, courts and other state institutions gathers increasing momentum, then recommendations for party and legislative strengthening to combine forces may easily get left behind. If party development is disadvantaged by this then the long term consequences may not serve 
legislative strengthening well, particularly in parliamentary systems. An issue-based approach to supporting legislative development by itself may do little to help party development. And in so far as it originates in the desire of development aid donors to promote their preferred choice of development strategies, democratic aims and objectives important to party support actors and legislative strengtheners in the democracy assistance world may come to be downgraded in relative terms too.

\section{REFERENCES}

Africa All Party Parliamentary Group (AAPPG)(2008), Strengthening Parliaments in Africa: Improving Support (London: House of Commons).

Barkan, J. (2007) 'Progress and retreat in Africa. Legislatures on the rise?, Journal of Democracy, 19 (2), pp. 124-37.

Brösamle, K., Dimsdale, T., Mathiesen, M. and T. Merz (2007), Improving Fiscal Scrutiny through Legislative Strengthening, available at http://www.sdnhq.undp.org/governance/parls/docs

Burnell, P. (2004) Building Better Democracies. Why political parties matter (London: Westminster Foundation for Democracy).

Burnell, P. (ed.) (2007), Evaluating Democracy Support. Methods and Experiences (Stockholm: International IDEA and SIDA). 
Carothers, T. (1999) Aiding Democracy Abroad. The Learning Curve (Washington, DC: Carnegie Endowment for International Peace).

Carothers, T. (2006) Confronting the Weakest Link. Aiding Political Parties in New Democracies (Washington, DC: Carnegie Endowment for International Peace).

Catón, M. (2007) Effective Party Assistance. Stronger Parties for Better Democracy (Stockholm: International IDEA Policy Paper).

Commonwealth Parliamentary Association (with UNDP, WBI and NDI)(2006), Benchmarks for Democratic Legislatures, available at http://sdnhq.undp.org/governance/parls/docs

Department for International Development (UK)(2004) Helping Parliaments and Legislative Assemblies to Work For the Poor, available at http://www.dfid.gov.uk

European Centre for Development Policy Management (2005) Institutional Evaluation of the Netherlands Institute for Multiparty Democracy, available at http://www.nimd.org

French, David (2008) 'Parliaments and parties: new directions for international democracy assistance', Parliamentary Monitor, available at http://www.wfd.org.

Fukuyama, F. and McFaul, M. (2007-08) 'Should democracy be promoted or demoted?' The Washington Quarterly, 31 (1), pp.23-45. 
Hubli, K. and Schmidt, M. (2007) Approaches to Parliamentary Strengthening. A Review of Sida's Support to Parliaments (Stockholm: SIDA Dept. for Democracy and Social Development).

Hudson, A. and Wren, C (2007) Parliamentary strengthening in developing countries. Final report for DFID (London: Overseas Development Institute).

Hudson, A. and Tsekpo, A. (2009) Parliamentary Strengthening and the Paris Principles. Synthesis Report (London: Overseas Development Institute).

Inter-Parliamentary Union, Ten Tears of Strengthening Parliaments in Africa, 19912000 (2003) Lessons learnt and the way forward. Report of a Joint IPU/UNDP Survey, available at http://www.ipu.org

Johnston, N. and von Trapp, L. (2008) Strengthening Parliaments - Strengthening Accountability. The World Bank Institute's Parliamentary Strengthening Program (World Bank Institute), available at http://www.siteresources.worldbank.org Jones, T. and Hardstaff, P. (2005) Denying Democracy. How the IMF and World Bank Take Power from the People (London, World Development Movement).

Krafchik, W. (2005) Can civil society add value to budget decision-making? A description of civil society budget work (2005), available at http://www.internationalbudget.org/resources/library/civilsociety.pdf 
McNeil, M. and Mumvuma, T. (2006) Demanding Good Governance. A Stocktaking of Social Accountability Initiatives by Civil Society in Anglophone Africa (Washington, DC: World Bank Institute), available at http://siteresources.worldbank.org

Michael, B. and Kasemets, A.(2007) 'The role of incentive design in parliamentarian anti-corruption programmes', Journal of Legislative Studies, 13 (2), pp. 280-300.

Miller, R. (2005) The Role of NGOs in International Democratic Development. The Case of Legislative Development (Montreal: Institute for Research on Public Policy), available at http://www.irpp.org

Murphy, J. and Alhada, A. (2007) Global Programme for Parliamentary Strengthening II Mid-term Evaluation Report (UNDP), available at http://sdnhq.undp.org/governance/parls/doc

Öhman, M., Öberg, S., Holmström, B., Wockelberg, H. and V. Åberg (2004) Political Parties and Democracy Assistance. An overview of the support provided by Swedish party associated organisations for democracy development in developing countries and countries in central and eastern Europe (Stockholm: Sida Evaluation 05/11).

Okole, H. (2008) Party regulation and political engineering in Papua New Guinea and the Pacific Islands, in: B. Reilly and P. Nordlund (eds) Political Parties in ConflictProne Societies, pp. 182-200 (Tokyo, New York, Paris: UNU Press). 
Power, G. (2008) Donor support to parliaments and political parties: An analysis prepared for DANIDA, available at http://www.um.dk and http://ddrn.dk

Reilly, B. and Nordlund, P.(eds) Political Parties in Conflict-Prone Societies (Tokyo, New York, Paris: UNU Press).

Schultz, K. (2007) USAID’s legislative strengthening performance measurements, available at http://sdnhq.undp.org/governanxce/parls/docs

Stapenhurst, R., Pelizzo, R., Olson, D. and von Trapp, L. (eds)(2008) Legislative Oversight and Government Accountability (Washington DC: World Bank).

UNDP (2003) Parliamentary Development Practice Note, available at http://www.undp.org/governance

UNDP (2005) Engagement with Political Parties, available at http://www.undp.org/oslocentre

United Nations Development Programme (2006) A Handbook on Working with Political Parties (New York: UNDP).

USAID (2000) Handbook on Legislative Strengthening, available at http://www.usaid.gov 
USAID (2006) International Legislative Strengthening: Alternate Approaches

(USAID and Financial Markets International), available at http://fmi-inc.net

Wehner, J. with Brösamle, K., Dimsdale, T., Mathiesen, M. and T. Merz (2007)

Strengthening Legislative Financial Scrutiny in Developing Countries, available at http://www.internationalbudget.org

Weir, S. and Beetham, D. (1999) Political Power and Democratic Control in Britain (London: Routledge).

World Bank and International Monetary Fund (2005) Synthesis 2005 Review of the PRSP Approach: Balancing Accountabilities and Scaling Up Results, available at http://siteresources.worldbank.org

Zimmermann, F. (2007) Report on Ownership in Practice (OECD Development Centre), available at http://www.oecd.org.

\section{NOTES}

1. Conceptual, methodological and source limitations make precise overall data elusive. For illustrative purposes, UNDP (2006: 11) says it supports one in three parliaments in the developing world in some way; and political parties in over 60 countries have received support from the US’s National Democratic Institute for International Affairs (NDI) according to information available at http://www.ndi.org 
2. Four substantial public meetings on parliaments and development organised by the UK’s Overseas Development Institute (ODI) and Africa All Party Parliamentary Group (AAPPG) in London, spring 2008 and a Wilton Park conference, 'Enhancing the Effectiveness of Parliaments: Challenges and Opportunities’, October 2008, underscore the point: summaries of the first are available at http://www.odi.org.uk.

3. See Michael and Kasemets (2007) and the exchange with Rick Stapenhurst of the World Bank Institute in Journal of Legislative Studies (2008), 14 (3), pp. 353-59.

4. September 2008 saw the publication of Legislative Oversight and Budgeting: A World Perspective, edited by R. Stapenhurst, R. Pelizzo, D. Olson and L. von Trapp (Washington DC: World Bank). For other development organisations like Britain’s Department for International Development (DFID), Brösamle, Dimsdale, Mathiesen and Merz (2007: 19) say that the ultimate purpose of supporting parliaments, their budget oversight function in particular, ‘is fairly obvious’: ‘promote development and reduce poverty’ and create 'the institutional conditions to make development aid effective'.

5. The UNDP's flagship Global Programme for Parliamentary Strengthening, with core funding of 6 million Euros for 2004-08, supports projects in 12 countries including Algeria, Benin, Morocco and Niger plus regional and global initiatives. WFD’s core programme countries include Belarus, Ukraine, Serbia, Egypt, Uganda, Kenya and Sierra Leone, the last being a special site of cross-party collaboration.

6. Around one sixth of the USAID bid is earmarked for 'political competition and consensus-building', less than for each of rule of law and human rights, 
good governance, and civil society. Over 1990-2006 USAID spent around $\$ 240$ million on legislative strengthening. Three quarters of SIDA’s parliamentary assistance is channelled through multilateral and international non-governmental organisations.

7. The PCC receives funding from bodies like the Canadian International Development Agency (CIDA), the World Bank, DFID and Denmark’s DANIDA. It has a long-standing involvement in helping develop the committee system of Ghana's parliament, among other programmes. It is currently field-testing a Parliamentary Report Card to assess parliamentary performance, starting with Cambodia.

8. CDI, an Australian government initiative in 1998 is funded by the Australian Agency for International Development.

9. See Inter-Parliamentary Union (2003): major findings included the observation that support did not correlate strongly with regime enthusiasm for democracy and good governance.

10. Hudson and Wren (2007), who found that DFID's 30 or so parliamentary strengthening projects since 1998 focused on parliament as an institution, the committee system for example, rather than training MPs or on the wider political system. DFID cosponsored a noteworthy international conference on 'Enhancing the effectiveness of parliaments: challenges and opportunities', at Wilton Park in October 2008.

11. Germany's Friedrich Ebert Stiftung, close to the Social Democratic Party and the Konrad Adenauer Stiftung, related to the Christian Democratic Union, are the mot active Stiftungen in democracy support; Sweden’s Olof Palme Center, 
linked to the country’s Social Democratic Party, similarly has partnerships with like-minded parties abroad.

12. On party strengthening see especially Carothers (2006) and Burnell (2004). The International Institute for Democracy and Electoral Assistance (IDEA), an inter-governmental policy research organisation based in Stockholm, offers commentary on party support, as in Catón (2007) for instance. The recent flurry of informative reports on legislative strengthening includes Hudson and Wren (2007), Hubli and Schmidt (2007), Murphy and Alhada (2007), Africa All Party Parliamentary Group (2008) and Huson and Tsekpo (2009). Significant studies from the WBI include N. Johnston and L. von Trapp (2008), following previous reports by Pelizzo, Stapenhurst and Olson.

13. The NDI now divides its party development support into four: operational and structural development; parties in elections; parties in parliament; legal and constitutional frameworks. Each is subdivided into further elements. NDI lists 12 criteria for selecting partners, and offers 14 different training techniques.

14. Wehner with Brösamle, Dimsdale, Mathiesen and Merz (2007: 38-9) distinguish between technical assistance in legal reform, developing structure and processes, improving information access, physical infrastructure development, budget training, study trips, and analytic work, before going on to identify the portfolios of globally active core actors categorised as either funders or implementers.

15. Hubli and Schmidt (2007: 17) too note that 'institutional repair' packages are no longer considered sufficient.

16. Hubli and Schmidt (2007) is a prime example; see also Michael and Kasemets (2007) and Hudson and Tsekpo (2009: 7). 
17. For example a survey in Malawi found that along with representation easily the most frequently cited expectation of an MP by Malawians is to deliver development: ‘An MP’s contribution to the collective functions of parliament such as legislation and holding the executive to account was not seen as important’ (AAPPG 2008: 23). See also Barkan (2007).

18. Apart from Power (2008: 23) other evidence includes study of programmes, direct communication from CDI and observations of NDI in the Balkans shared by Maja Nenadović, complementing Miller's (2005: 10-11) characterisation of 'organizational silos' and 'tunnel behaviour' among Canadian organisations supporting democratic development. CDI’s support for strengthening party discipline in Papua New Guinea’s (PNG) parliament even had the aim of ending chronic government instability, which looks contrary to the objective of legislative strengthening. However, floor-crossing in parliament and mid-term upheavals had formerly undermined governmental accountability all round (Okole 2008).

19. Catón (2007) for instance does not mention cooperation with legislative strengthening.

20. UNDP (2005) subsequently listed 14 country offices engaged in capacity development for MPs, 13 each for parties and enhancing party dialogue, 11 for increasing women's participation, 7 for strengthening party systems and 10 for improving electoral systems, in 43 countries.

21. A further example is Rasheed Draman speaking in the fourth ODI/AAPPG meeting mentioned in note 2. Together with the Overseas Office of the House of Commons, National Audit Office, UK branch of the CPA and other organisations, WFD in 2007 set up a Westminster Consortium for Parliaments; 
around the same time Hilary Benn (as Britain’s Secretary of State for International Development) publicly called on DFID, WFD, FCO, IPU and European Parliament to work together in parliamentary strengthening, in ‘Governance, Democracy and Parliaments', available at http:///www.dfid.gov.uk

22. Reilly and Nordlund (2008) examine the effects of party regulation and electoral system engineering on parties.

23. For example, AAPPG (2008: 27-8), citing evidence from Malawi and Kenya.

24. The European Centre for Development Policy Management (2005) evaluation of NIMD was largely positive.

25. See for example USAID (2006), Wehner et al. (2007), Hubli and Schmidt (2007), Johnston and von Trapp (2008).

26. Of course there could be other issues like the environment or gender equity where policy support from outside is appropriate and might be welcome.

27. AAPPG (2008: 18) says that in donor eyes 'parliament is often seen more as a part of the problem than part of the solution'.

28. In Africa for instance while support for social accountability is said to be in its infancy the demand is judged to be high (McNeil and Mumvuma 2006).

29. 'Development partners need to be aware of (and not bypass) participatory and representative processes and institutions that already exist' (World Bank and International Monetary Fund 2005: 10).

30. On parliaments' role in ensuring more effective and accountable aid see for example AAPPG (2008:19-20). Wehner et al. (2007) identify 15 international organisations now offering significant support to improving legislative financial scrutiny specifically. 
31. That the policy frameworks often still originate with donors is attested to by commentators as diverse as the World Development Movement's Jones and Hardstaff (2005), Hubli and Schmidt (2007: 23), and Zimmermann (2007), the last arguing for increased parliamentary involvement in development planning, policy and budgeting. AAPPG (2008: 7) adds that direct budget support particularly in Africa risks making the governments 'more accountable to donors and less accountable to their people'.

32. Between 2001 and 2004 DFID spent $£ 4.4$ million on promoting closer working between parliament and civil society and strengthening parliamentary committees in Malawi.

33. Also, Hudson and Tsekpo (2009: 1): 'there is little systematic research or analysis about the effectiveness of parliaments or about the effectiveness of parliamentary strengthening’ more generally. But on Africa see Barkan (2007) for a useful contribution. 